\section{Språkspalten er 20 år!}

\author{
I 1990 ble Tidsskriftets språkspalte lansert. Aktiviteten har tidvis vært \\ høy og ført til fruktbare diskusjoner.
}

«Tidsskriftet står sentralt i utviklingen av et norsk medisinsk språk. Som et uttrykk for dette, oppretter vi i dette nummeret en språkspalte som vil komme med uregelmessige mellomrom. Det er ikke noe spesielt originalt tiltak, men forhåpentligvis nyttig likevel.» Slik introduserte daværende redaktør Magne Nylenna den nye spalten i Tidsskriftet 30. mai 1990 (1). Spalten har vist seg livskraftig, og innlegg om språk finnes nå i hvert nummer av Tidsskriftet.

Bidragene fra disse 20 årene er svært varierte. En av de mest omfattende debattene gjaldt skrivemåten $\mathrm{AB} 0 / \mathrm{ABO}$ med hele 13 bidrag i årene 1996-98. Ikke sjelden kommer temaer opp på ny, så også i dette tilfellet; foreløpig siste innlegg sto på trykk våren 2010. Skal ord som nevrologi og revmatologi skrives med eu eller ev? Dette var et annet spørsmål som skapte engasjement (2). De fleste bidragsyterne har holdt seg innenfor rammen på 400 ord (3), men det har også vært rom for lengre innlegg (4). Spalten har dessuten vært stedet for lanseringen av fornorskede uttrykk, som blinkcelle for «target cell» (1990), enkeltnukleotidpolymorfisme (2005) og enkeltbasevariasjon (2007) for «single nucleotide polymorphism». Spalten har vært åsted for lansering av nyord som risikant (1994), men også ofte for omtale av begreper som ikke lenger har livets rett, som MT (forkortelse for magnetisk resonanstomografi) (1999) og serumspeil (2007). Det har vært innlegg om ortografi, etymologi, uttale, grammatikk og omtale av medisinske ordbøker. Språkblomster fra innsendte manus har vært et jevnlig innslag.

Nytten av Språkspalten er minst like stor i dag som for 20 år siden. I dag er idealet parallellspråklighet, dvs. at man satser på både engelsk og nasjonalspråket (5). Det krever vedlikehold og utvikling av norsk medisinsk terminologi - og til det trengs en vedvarende dugnad (6). Oppfordringen fra 1990 står derfor fremdeles ved lag:

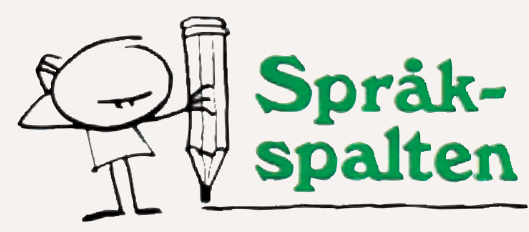

Vignetten som ble brukt de første årene

«Vi mottar gjerne kommentarer og meningsytringer om spalten, men skriv kort og konsist!«

\section{Erlend Hem}

erlend.hem@medisin.uio.no

Tidsskriftet

\section{Litteratur}

1. Nylenna M. Språkspalten. Tidsskr Nor Lægeforen 1990; 110: 1871.

2. Ødegaard R. Språket i Tidsskriftet. Tidsskr Nor Lægeforen 2006; 126: 71.

3. Språkspalten. Forfatterveiledningen. Tidsskrift for Den norske legeforening. www.tidsskriftet.no/ index.php? nota id=548 (7.6.2010).

4. Bjørkum A, Biørkum R, Stavem P. Orda slapp og sjuk har mange synonym og dialektuttrykk Tidsskr Nor Lægeforen 1993; 113: 3813-8.

5. St.meld. nr. 35 (2007-2008). Mål og meining: ein heilskapleg norsk språkpolitikk.

6. Myking J. Terminologiutvikling - kulturpolitikk og sosialpolitikk. Tidsskr Nor Legeforen 2008; 128 : 850

alle pasienter å fastslå om utfallene helt sikkert skyldes akutt hjerneslag.

- Det er også laget en video av undersøkelse av nyfødte og ettåringer til utlån.

- Vi inkluderte de som var oppfattet som, og ble behandlet som skafoidfrakturer.

- Det summar i mange slags språk, nokre er fortvila, nokre openbert sjuke, andre sterkt påverka av både legale og illegale rusmiddel.

\section{Raida Ødegaard}

raida.oedegaard@legeforeningen.no

Tidsskriftet

- Laboranten skrev daglig ut dødsattest på alle inneliggende pasienter.

bildedannende teknologi.

- I klinisk praksis er det ofte ikke mulig for

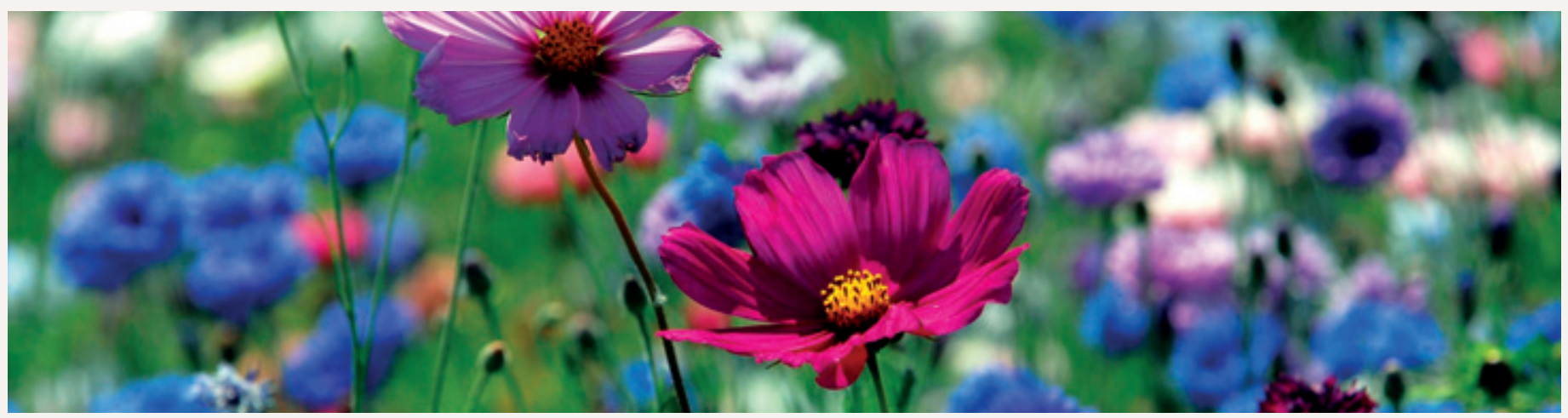

